\title{
Kajian Daya Dukung Lingkungan dalam Pemanfaatan Ruang di Kawasan Bandung Utara
}

\author{
Environmental Carrying Capacity Study in the Spatial Use of \\ Northern BandungArea
}

\section{Putraarta Samodro 1}

Program Studi Magister Inovasi Regional, Sekolah Pascasarjana

Universitas Padjadjaran, Bandung, Indonesia

\section{Mudiyati Rahmatunnisa}

Program Studi Magister Inovasi Regional, Sekolah Pascasarjana

Universitas Padjadjaran, Bandung, Indonesia

\section{Cipta Endyana}

Fakultas Teknik Geologi, Universitas Padjadjaran, Bandung, Indonesia

Artikel Masuk : 24 Juni 2020

Artikel Diterima : 26 Oktober 2020

Tersedia Online : 31 Desember 2020

\begin{abstract}
Abstrak: Kawasan Bandung Utara (KBU) memegang peranan dan fungsi vital terhadap wilayah di sekitarnya karena KBU merupakan daerah resapan air. Rencana Tata Ruang Wilayah (RTRW) Provinsi Jawa Barat mengarahkan KBU sebagai Kawasan Strategis Provinsi (KSP) bidang penanganan lingkungan hidup. Pengendalian tata ruang KBU saat ini diatur dengan Peraturan Gubernur Nomor 2 Tahun 2016 tentang Pedoman Pengendalian Kawasan Bandung Utara Sebagai Kawasan Strategis Provinsi Jawa Barat. Pembangunan yang dilakukan di KBU harus memerhatikan daya dukung lingkungan, sehingga program pemanfaatan ruang yang akan dijadikan sebagai regulasi dalam dokumen tata ruang telah berbasis daya dukung lingkungan. Penelitian ini bertujuan untuk melakukan analisis daya dukung lingkungan terhadap penggunaan lahan, serta merumuskan rekomendasi program dalam pemanfaatan ruang di KBU. Pendekatan yang digunakan adalah aplikasi metode indeks konservasi dalam penyusunan rekomendasi program pemanfaatan ruang. Hasil analisis menunjukkan bahwa penggunaan lahan tahun 2015 telah menurunkan fungsi konservasi aktual yang menyebabkan adanya wilayah konservasi kritis sebesar $68,37 \%$ dan meningkat pada tahun 2018 menjadi 69,78\%. Aplikasi indeks konservasi pada arahan rencana pola ruang RTRW Provinsi Jawa Barat menunjukkan turunnya wilayah konservasi kritis menjadi 35,90\% pada tahun 2029. Penurunan wilayah konservasi kritis tahun 2029 belum ditunjang oleh program-program lingkungan dalam perwujudan rencana pola ruang yang mampu meningkatkan kelas konservasi baik sebesar 42,27\%, ketika pada tahun 2018 kelas konservasi baik hanya sebesar 10,78\%. Dapat disimpulkan bahwa kajian IKA dan IKC yang telah dilakukan dalam penelitian ini memperlihatkan adanya pertambahan sebaran lahan kritis di
\end{abstract}

\footnotetext{
1 Korespondensi Penulis: Program Studi Magister Inovasi Regional, Sekolah Pascasarjana Universitas Padjadjaran, Bandung, Indonesia

Email: putraarta18001@mail.unpad.ac.id
} 


\title{
215 Kajian Daya Dukung Lingkungan dalam Pemanfaatan Ruang di Kawasan Bandung Utara
}

KBU, serta analisis IKR membuktikan bahwa rencana pola ruang RTRW Provinsi Jawa Barat akan mampu menurunkan wilayah konservasi kritis.

Kata Kunci: daya dukung lingkungan; indeks konservasi; Kawasan Bandung Utara; pemanfaatan ruang

\begin{abstract}
Northern Bandung Area (KBU) plays a vital role and function to surrounding areas as a groundwater catchment area. The West Java Province Spatial Plan (RTRW) stipulates $K B U$ as the Provincial Strategic Area (KSP) for environmental protection. The spatial control governance over the KBU is currently regulated by the Governor Regulation Number 2 Year 2016 about Guidelines for Controling the Northern Bandung Area as the the West Java Province Strategic Area. The KBU development ought to take environmental carrying capacity into account concerning the completion of environmentally based spatial use programs in the $K B U$. This study aimed to analyze the environmental carrying capacity of land use, and to formulate program recommendation of desired spatial use in $K B U$. Conservation index method was used to analyze environmental carrying capacity necessary to spatial use program recommendation. The results showed that the land use coverage in 2015 decreased actual conservation function, creating an increase of critical conservation areas by $68.37 \%$ and by $69.78 \%$ in 2018. In contrast, the conservation index on the land use plan in the RTRW showed a decrease in critical conservation area to $35.90 \%$ in 2029. However, such a declining figure has not been supported by environmental programs in the land use plan implementation required to increase the good conservation class by $42.27 \%$ while it recorded by $10.78 \%$ in 2018. It can be concluded that the IKA and IKC studies showed a distribution expansion of critical lands in KBU, and the IKR analysis proved that the land use plan in the $R T R W$ would reduce critical conservation areas.
\end{abstract}

Keywords: conservation index; environmental carrying capacity; Northern Bandung Area; spatial planning

\section{Pendahuluan}

Kawasan Bandung Utara (KBU) merupakan salah satu kawasan yang sangat strategis dilihat dari kondisi sosial, ekonomi, dan fisik karena letaknya di wilayah Cekungan Bandung yang merupakan ibukota dan Pusat Kegiatan Nasional di Provinsi Jawa Barat. KBU merupakan kawasan lintas kabupaten/kota yang meliputi sebagian daerah Kabupaten Bandung, Kota Bandung, Kota Cimahi, dan Kabupaten Bandung Barat (Pemerintah Daerah Provinsi Jawa Barat, 2016).

Penataan ruang di Provinsi Jawa Barat telah diatur dalam Peraturan Daerah Provinsi Jawa Barat Nomor 22 Tahun 2010 tentang Rencana Tata Ruang Wilayah Provinsi Jawa Barat. Dalam peraturan ini KBU diarahkan sebagai Kawasan Strategis Provinsi (KSP) untuk kepentingan fungsi dan daya dukung lingkungan hidup (Pemerintah Daerah Provinsi Jawa Barat, 2010).

Selain itu telah ada pula Peraturan Gubernur Jawa Barat Nomor 2 Tahun 2016 tentang Pedoman Pengendalian Kawasan Bandung Utara Sebagai Kawasan Strategis Provinsi Jawa Barat. Peraturan Gubernur ini mengarahkan bahwa pemanfaatan ruang kawasan budi daya di KBU dilakukan dengan mempertimbangkan daya dukung dan daya tampung lingkungan (Pemerintah Daerah Provinsi Jawa Barat, 2016).

Pada tingkat nasional, terdapat Peraturan Presiden Nomor 45 Tahun 2018 tentang Rencana Tata Ruang Kawasan Perkotaan Cekungan Bandung. Peraturan ini mengarahkan pengembangan Kawasan Perkotaan Cekungan Bandung bagian utara secara terbatas dengan memerhatikan daya dukung dan daya tampung lingkungan untuk mendukung 
kegiatan permukiman, pertanian, pariwisata, dan konservasi (Pemerintah Republik Indonesia, 2018).

Berdasarkan kebijakan yang ada, KBU memegang peranan dan fungsi vital terhadap wilayah di sekitarnya. Fungsi utama KBU terhadap kota dan kabupaten di bawahnya begitu penting karena KBU merupakan daerah resapan air, yang artinya selain berfungsi sebagai penghalang terjadinya banjir juga merupakan sumber mata air utama daerah Bandung Raya. Namun fungsi vital yang dimiliki KBU terhadap daerah-daerah di sekelilingnya tersebut tetap tidak menghalangi maraknya alih fungsi lahan di kawasan ini.

Maraknya pembangunan di KBU menunjukkan kondisi yang mengkhawatirkan. Koefisien Wilayah Terbangun sudah mencapai lebih dari $70 \%$ yang berdampak pada kerusakan lingkungan, ekologis dan memberikan dampak sosial ekonomi bagi masyarakat di wilayah KBU, padahal KBU sudah ditetapkan sebagai kawasan konservasi yang memberikan perlindungan ekologis dan kebutuhan air bagi wilayah di bawahnya (Sagita, 2016). Tingkat kerawanan perubahan penggunaan lahan di KBU sangat tinggi akibat tingkat perkembangan pusat pertumbuhan di KBU yang sangat cepat (Hernawan et al., 2009).

Tindakan pengelolaan tanaman dan tanah yang telah dilakukan petani selama ini di KBU belum mampu menekan laju erosi, sehingga perlu tindakan konservasi yang tepat dan sesuai dengan kondisi agroekosistem setempat dengan memerhatikan keseimbangan aspek konservasi dan penggunaannya (Sutrisna et al., 2010). KBU terancam akan beralih fungsi dari kawasan konservasi menjadi kawasan pemukiman, yang akan mengakibatkan banjir dan tanah longsor. Fungsi izin sebagai pengendali pemanfaatan ruang di KBU pada kenyataannya masih jauh dari yang diharapkan (Adharani \& Nurzaman, 2017). Sebagian wilayah KBU (Kawasan Ciburial) pada rentang tahun 2007 sampai tahun 2015 telah menunjukkan terjadinya peningkatan sebaran lahan kritis. Sebaran lahan kritis tersebut didapatkan dengan menggunakan analisis indeks konservasi (Nurrachman et al., 2018). Kerusakan lingkungan yang terjadi di KBU disebabkan oleh laju pertumbuhan penduduk yang relatif cepat dan kemajuan ilmu pengetahuan dan tehnologi (Afandi, 2014).

Faktor kebijakan tata ruang dalam mengendalikan alih fungsi daerah resapan air berpengaruh terhadap alih fungsi menjadi lahan terbangun di KBU. Kebijakan tata ruang dalam mengendalikan dan mencegah terjadinya alih fungsi lahan terbangun masih rendah dalam implementasinya dikarenakan belum terperincinya kawasan di daerah resapan air yang tidak boleh diperuntukkan bagi suatu bangunan (Putri \& Purwadio, 2013).

Terjadinya alih fungsi lahan di KBU memerlukan pengendalian dalam tahap pelaksanaan pola pemanfaatan ruang RTRW kota/kabupaten di KBU. Berdasarkan hal tersebut, perlu adanya penelitian lanjutan tentang masalah banjir dan genangan akibat berubahnya fungsi lahan di KBU secara menyeluruh dengan mempertimbangkan beberapa faktor baik teknis maupun non teknis, antara lain faktor infiltrasi (Nurrochman et al., 2018).

Kajian KBU yang telah dirumuskan oleh Nurrachman et al. (2018), Adharani \& Nurzaman (2017), Sagita (2016), Afandi (2014), Putri \& Purwadio (2013), Sutrisna et al. (2010), dan Hernawan et al. (2009) lebih fokus pada alih fungsi lahan yang akan mengakibatkan terjadinya bencana, kerusakan lingkungan akibat pertumbuhan penduduk, perubahan tutupan lahan dan konservasi air tanah dengan analisis indeks konservasi pada sebagian wilayah KBU, konservasi lahan dari aspek pola tanam, serta solusi penanganan KBU yang didasarkan aspek perizinan. Dalam hal ini, belum adanya penelitian yang membahas tentang kajian konservasi dari faktor infiltrasi yang memerhatikan keseimbangan lingkungan terhadap penggunaan lahan yang ada di seluruh wilayah KBU, serta pengendalian pelaksanaan pola pemanfaatan ruang RTRW yang mempertimbangkan faktor infiltrasi.

Oleh karena itu penelitian ini difokuskan pada kajian daya dukung lingkungan terkait faktor infiltrasi yang ada akibat perkembangan penggunaan lahan, serta bagaimana pengaruhnya terhadap kebijakan tata ruang yang ada. Penelitian ini bertujuan untuk 


\section{Kajian Daya Dukung Lingkungan dalam Pemanfaatan Ruang di Kawasan Bandung Utara}

melakukan analisis daya dukung lingkungan terhadap penggunaan lahan serta merumuskan rekomendasi program dalam pemanfaatan ruang RTRW di KBU.

\section{Metode Penelitian}

\section{Lokasi Studi}

Wilayah administrasi KBU meliputi tiga kecamatan di Kabupaten Bandung, 10 kecamatan di Kota Bandung, dua kecamatan di Kota Cimahi, serta enam kecamatan di Kabupaten Bandung Barat. Secara geografis, KBU terletak antara $107^{\circ} 27^{\prime}$ - $107^{\circ}$ Bujur Timur, 60 44' - 60 56' Lintang Selatan..

\section{Metode Pengumpulan Data}

Metode pengumpulan data dalam penelitian ini dilakukan dengan cara pengambilan data dari berbagai instansi terkait, meliputi berbagai jenis data dan peta (curah hujan, jenis batuan, jenis tanah, morfologi, dan penggunaan lahan) serta kebijakan terkait (Rencana Tata Ruang Wilayah Provinsi Jawa Barat). Data yang digunakan dalam penelitian ini berupa data sekunder, yaitu sumber data yang tidak langsung memberikan data kepada pengumpul data yang sifatnya mendukung keperluan data primer seperti buku-buku, literatur dan bacaan yang berkaitan dan menunjang penelitian ini (Sugiyono, 2017).

\section{Analisis Indeks Konservasi}

Indeks Konservasi (IK) adalah suatu koefisien yang menunjukkan kemampuan suatu wilayah untuk menyerap air hujan yang jatuh ke permukaan tanah dan menjadi imbuhan air tanah yang dihitung berdasarkan variabel curah hujan, jenis batuan, kemiringan lereng, jenis tanah dan penggunaan lahan. Dalam penilaiannya, indeks ini terdiri dari Indeks Konservasi Alami (IKA) dan Indeks Konservasi Aktual (IKC) (Lestiana et al., 2019). Faktor yang membedakan kondisi alami dan aktual adalah pada jenis penggunaan lahannya.

IKA yaitu suatu koefisien yang menunjukkan kemampuan alami pada suatu wilayah untuk menyerap air hujan yang jatuh ke permukaan tanpa adanya campur tangan manusia. IKA merupakan fungsi dari curah hujan, jenis batuan, jenis tanah, dan morfologi. Adapun IKC merupakan fungsi dari curah hujan, jenis batuan, jenis tanah, morfologi dan penggunaan lahan (Maria \& Lestiana, 2014). Air hujan yang jatuh selanjutnya akan menjadi air limpasan (run off) dan menyerap ke dalam tanah (infiltrasi) sesuai hukum kekekalan massa air, yaitu bila kesetimbangan massa $\mathrm{P}=\mathrm{I}+\mathrm{R}$ maka $(\mathrm{P})$ adalah curah hujan, (I) adalah infiltrasi dan $(\mathrm{R})$ adalah air limpasan (Tigana \& Sabar, 2019).

Setiap parameter pada IKA dan IKC akan dibagi menjadi lima kelas dengan pembobotan. Penilaian yang akan diberikan adalah berdasarkan pada pengaruh setiap parameter terhadap nilai indeks konservasi. Parameter yang memberikan pengaruh rendah akan diberikan bobot yang kecil, sebaliknya jika pengaruhnya tinggi akan diberikan bobot yang besar. Setiap bobot pada parameter indeks konservasi akan dijumlahkan dan menghasilkan nilai pada kelas indeks konservasi (Tabel 1).

Tabel 1. Penilaian Bobot Indeks Konservasi

\begin{tabular}{ccc}
\hline Kelas & Jumlah Bobot & Nilai IK \\
\hline Rendah & $5-8$ & $<0,33$ \\
Agak Rendah & $9-12$ & $0,33-0,48$ \\
Sedang & $13-16$ & $0,49-0,64$ \\
Tinggi & $17-20$ & $0,65-0,8$ \\
Sangat Tinggi & $21-25$ & $>0,8$ \\
\hline
\end{tabular}

Sumber: Maria \& Lestiana, 2014 
Komponen IKA dan IKC digunakan untuk melakukan evaluasi pemanfaatan ruang melalui analisis data spasial. Evaluasi ini didapat dengan membandingkan antara nilai IKA dan IKC, yang dapat dijadikan suatu panduan pengendalian pemanfaatan ruang. Lahan terdegradasi atau lahan kritis dapat dijelaskan dengan melakukan evaluasi perbandingan nilai IKA dan IKC ini (Marselina et al., 2020). Penilaian terhadap kondisi penggunaan lahan dalam suatu kawasan dapat dilihat dari perbandingan nilai IKC dan nilai IKA (Tabel 2).

Tabel 2. Penilaian Kondisi Pemanfaatan Ruang

\begin{tabular}{cc}
\hline Hubungan Nilai Indeks Konservasi & Parameter \\
\hline $\mathrm{IK}_{\mathrm{C}}>\mathrm{IK}_{\mathrm{A}}$ & Baik \\
$\mathrm{IK}_{\mathrm{C}}=\mathrm{IK}_{\mathrm{A}}$ & Normal \\
$\mathrm{IK}_{\mathrm{C}}<\mathrm{IK}_{\mathrm{A}}$ & Kritis \\
\hline
\end{tabular}

Sumber: Maria \& Lestiana, 2014

\section{Analisis Spasial}

Kesesuaian lahan berdasarkan indeks konservasi dianalisis dengan melakukan pembobotan pada parameter tertentu dan proses klasifikasi secara spasial (Lestiana et al., 2019). Metode penelitian ini menggunakan metode deskriptif kuantitatif dengan menggunakan pendekatan analisis spasial menggunakan bantuan aplikasi Sistem Informasi Geografis (SIG) dan analisis skoring (Da Costa et al., 2019).

\section{Hasil dan Pembahasan}

\section{Curah Hujan}

Pembagian kelas curah hujan berdasarkan kepada curah hujan tahunan dengan rentang $500 \mathrm{~mm} /$ tahun (Tabel 3). Curah hujan di KBU berada pada kelas < 2.500 $\mathrm{mm} /$ tahun, yaitu berkisar antara $1.500-2.500 \mathrm{~mm} /$ tahun. Curah hujan ini termasuk ke dalam kategori curah hujan sangat rendah (Gambar 1).

Tabel 3. Pembagian Kelas Curah Hujan

\begin{tabular}{ccc}
\hline Curah Hujan Tahunan $(\mathbf{m m} / \mathbf{t h})$ & Deskripsi & Nilai \\
\hline$>4000$ & Sangat Tinggi & 5 \\
$3500-4000$ & Tinggi & 4 \\
$3000-3500$ & Sedang & 3 \\
$2500-3000$ & Rendah & 2 \\
$<2500$ & Sangat Rendah & 1 \\
\hline
\end{tabular}

Sumber: Maria \& Lestiana, 2014

\section{Jenis Batuan}

Pembagian kelas jenis batuan didasarkan pada kemampuan dari tiap jenis litologi untuk menyerapkan air sebagai air imbuhan ke dalam tanah (Tabel 4). Dominasi jenis batuan berupa GA Tua Fm Cikapundung yang memiliki koefisien resapan 0,15 (Gambar 2).

Tabel 4. Pembagian Kelas Jenis Batuan

\begin{tabular}{ccc}
\hline Geologi/Jenis Batuan & Deskripsi & Nilai \\
\hline Fm. Cibereum & Sangat Tinggi & 5 \\
Hasil G.A Muda Fm. Cikidang, Fm Kosambi & Tinggi & 4 \\
Hasil G.A Tua Fm Cikapundung & Sedang & 3 \\
Endapan Tersier Laut dan Vulkanik & Rendah & 2 \\
Lava Andesit & Sangat Rendah & 1 \\
\hline
\end{tabular}

Sumber: Maria \& Lestiana, 2014 


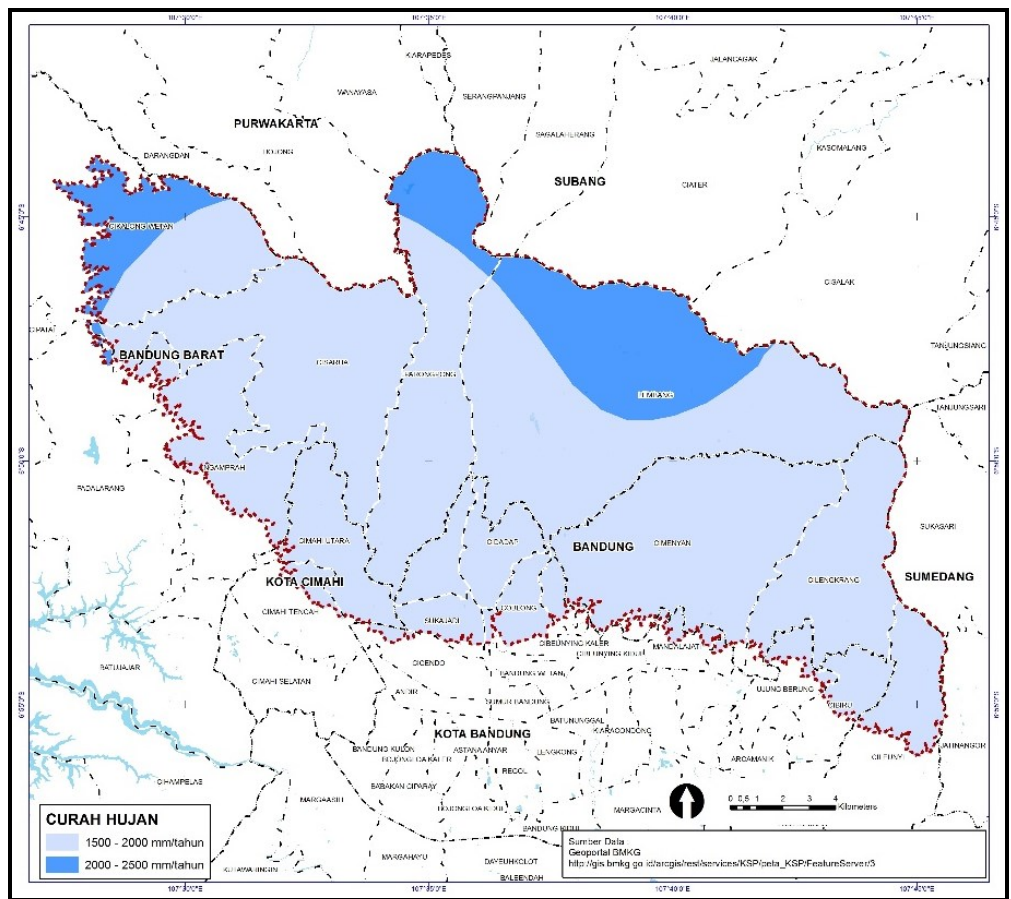

Sumber: Geoportal BMKG, 2015

Gambar 1. Peta Curah Hujan KBU

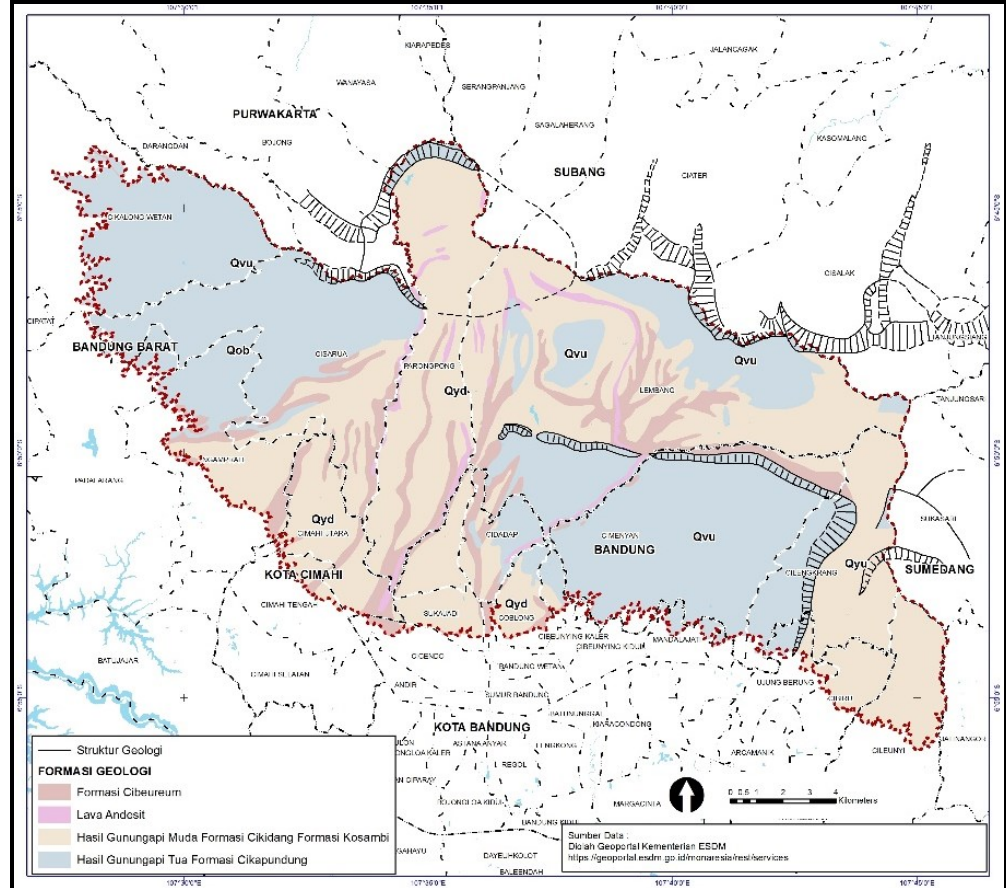

Sumber: Silitonga, 1973 diolah

Gambar 2. Peta Jenis Batuan 


\section{Jenis Tanah}

Pembagian jenis tanah didasarkan pada kemampuan tanah untuk meresapkan dan melimpaskan air hujan (Tabel 5). Dominasi jenis tanah adalah andisol yang memiliki permeabilitas agak cepat (Gambar 3).

Tabel 5. Pembagian Kelas Jenis Tanah

\begin{tabular}{cccc}
\hline Jenis Tanah & Permeabilitas & Deskripsi & Nilai \\
\hline Kompleks Entisol & Cepat $(>30)$ & Sangat Tinggi & 5 \\
Andisol & Agak Cepat $(15-30)$ & Tinggi & 4 \\
Inceptisol & Sedang-Cepat $(7-15)$ & Sedang & 3 \\
Kompleks Ultisol & Agak Lambat $(2-7)$ & Rendah & 2 \\
Tanah Alluvial & Lambat $(<2)$ & Sangat Rendah & 1 \\
\hline
\end{tabular}

Sumber: Maria \& Lestiana, 2014

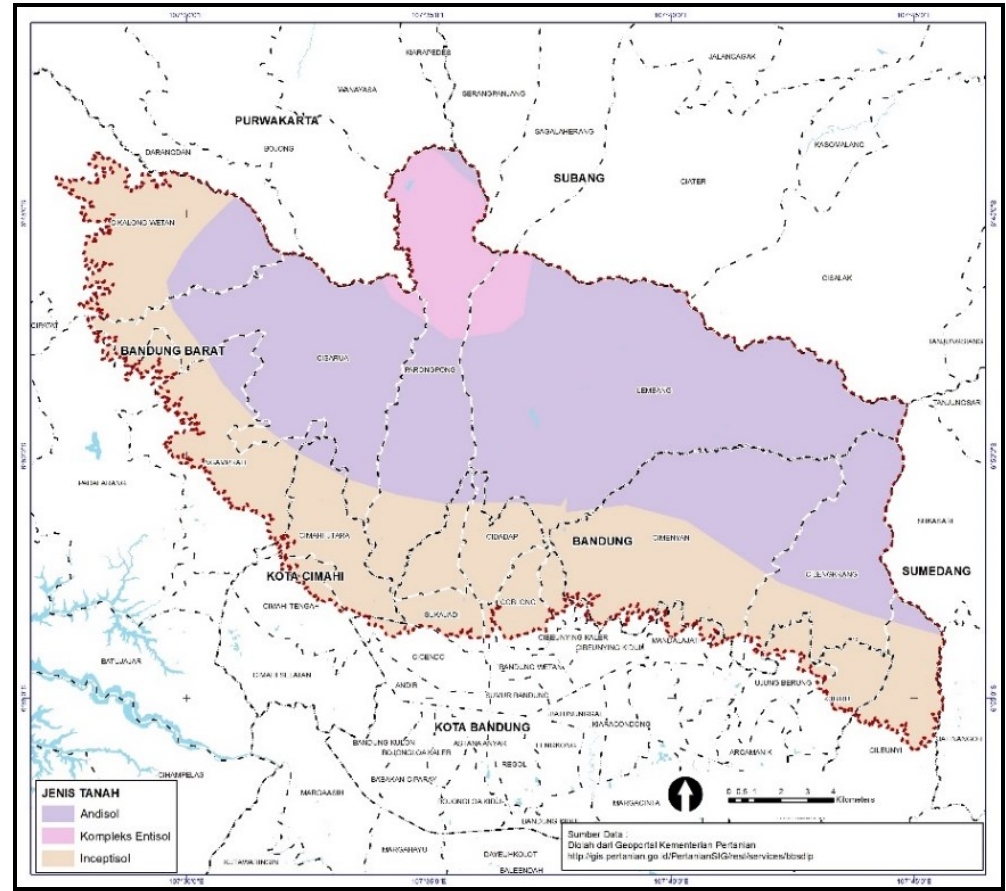

Sumber: Litbang Pertanian, 2017 diolah

Gambar 3. Peta Jenis Tanah KBU

\section{Morfologi}

Di dalam pembagian kelas morfologi didasarkan pada kemiringan lereng (sudut yang dibentuk oleh bidang horizontal dengan permukaan tanah) nilainya dinyatakan dalam derajat atau persen (Tabel 6). Kemiringan lereng di KBU didominasi oleh kemiringan lereng 8-15\% (landai), mencapai 43\% dari luas wilayah KBU (Gambar 4).

Tabel 6. Pembagian Kelas Morfologi

\begin{tabular}{cccc}
\hline & Kemiringan Lereng & Deskripsi & Nilai \\
\hline$<8 \%$ & Datar & Sangat Tinggi & 5 \\
$8-15 \%$ & Landai & Tinggi & 4 \\
$15-25 \%$ & Bergelombang & Sedang & 3 \\
$25-40 \%$ & Curam & Rendah & 2 \\
$>40 \%$ & Sangat Curam & Sangat Rendah & 1 \\
\hline
\end{tabular}

Sumber: Maria \& Lestiana, 2014 


\section{Penggunaan Lahan}

Pembagian kelas penggunaan lahan berdasarkan banyaknya kanopi daun yang menutupi suatu wilayah, karena kanopi tersebut memengaruhi besarnya infiltrasi di daerah tersebut seperti ditampilkan pada Tabel 7 (Maria \& Lestiana, 2014). Penggunaan lahan KBU tahun 2015 didominasi oleh tegal/ladang yang mencapai 42\%. Sementara penggunaan lahan tahun 2018 masih didominasi oleh tegal/ladang dengan proporsi yang lebih kecil yaitu mencapai 32\% (Gambar 5).

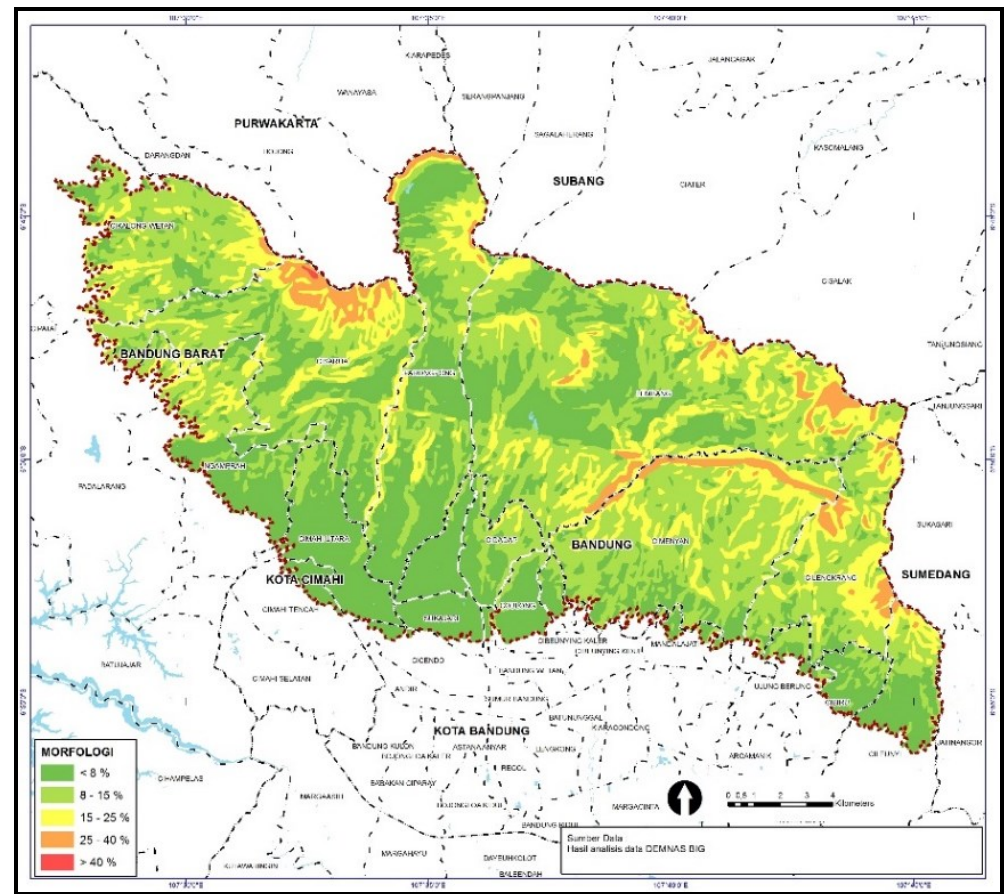

Sumber: Geoportal BIG, 2011 diolah

Gambar 4. Peta Morfologi KBU

Tabel 7. Pembagian Kelas Penggunaan Lahan

\begin{tabular}{ccc}
\hline Penggunaan Lahan & Deskripsi & Nilai \\
\hline Hutan & Sangat Tinggi & 5 \\
Perkebunan/Kebun & Tinggi & 4 \\
Tegal/Ladang & Sedang & 3 \\
Sawah & Rendah & 2 \\
Permukiman/Lahan Terganggu & Sangat Rendah & 1 \\
\hline
\end{tabular}

Sumber: Maria \& Lestiana, 2014

\section{Perubahan Penggunaan Lahan}

Perubahan penggunaan lahan dianalisis berdasarkan peta penggunaan lahan tahun 2015 dan 2018. Berdasarkan analisis tersebut diketahui terjadi beberapa perubahan pemanfaatan ruang (Tabel 8). Perluasan kawasan permukiman dikhawatirkan akan menurunkan nilai konservasi kawasan secara keseluruhan. Perubahan penggunaan lahan di KBU didominasi oleh pergeseran kawasan tegal/ladang menjadi kawasan permukiman, serta kawasan perkebunan/kebun menjadi sawah dan permukiman. 


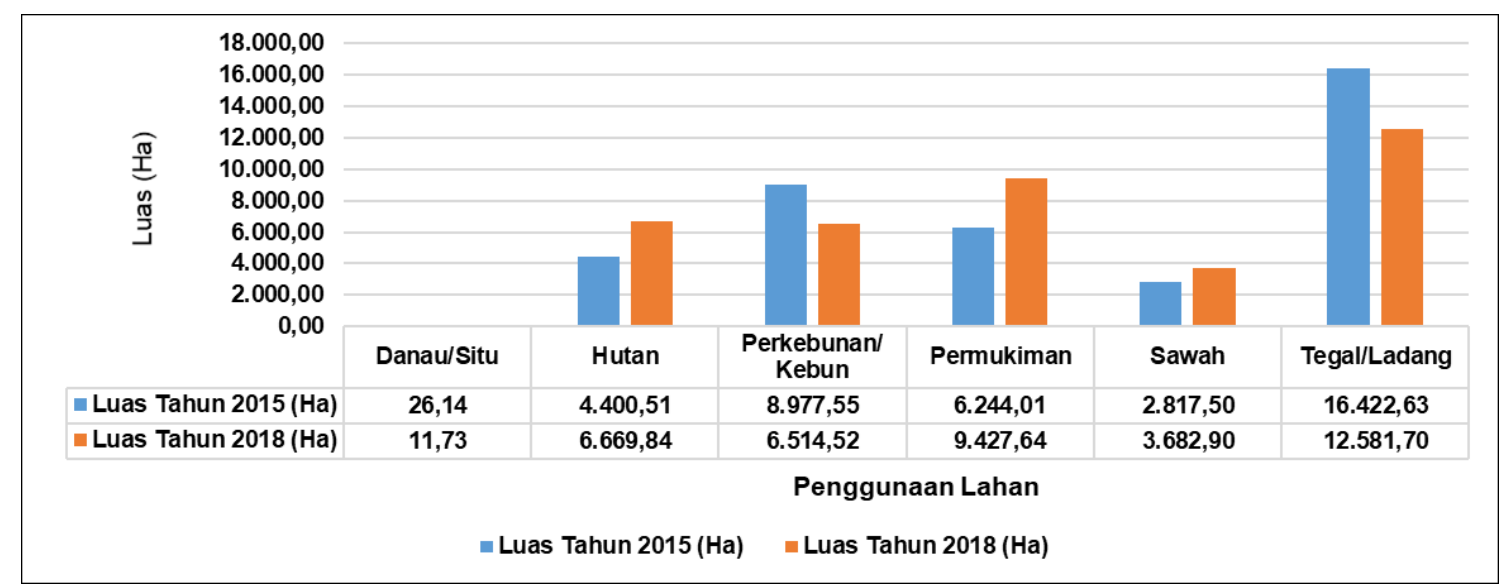

Sumber: Geoportal BIG, 2015 dan Geoportal Lapan, 2018 diolah

Gambar 5. Penggunaan Lahan di KBU Tahun 2015 dan 2018

Tabel 8. Nilai Perubahan Luas Penggunaan Lahan Tahun 2015-2018

\begin{tabular}{lrrrrrr}
\hline \multicolumn{1}{c}{$\begin{array}{c}\text { Penggunaan } \\
\text { Lahan }\end{array}$} & \multicolumn{1}{c}{$\begin{array}{c}\text { Luas } \\
\mathbf{2 0 1 5}\end{array}$} & $\mathbf{2 0 1 5}$ & \multicolumn{1}{c}{$\begin{array}{c}\text { Luas } \\
\mathbf{2 0 1 8}\end{array}$} & \multicolumn{1}{c}{$\mathbf{2 0 1 8}$} & \multicolumn{1}{c}{$\begin{array}{c}\text { Perubahan } \\
\text { (Ha) }\end{array}$} & \multicolumn{1}{c}{$\begin{array}{c}\text { Perubahan } \\
\text { (\%) }\end{array}$} \\
\hline Danau/Situ & 26,14 & 0,07 & 11,73 & 0,03 & $(14,40)$ & $(0,04)$ \\
Hutan & $4.400,51$ & 11,32 & $6.669,84$ & 17,15 & $2.269,33$ & 5,84 \\
Perkebunan/Kebun & $8.977,55$ & 23,09 & $6.514,52$ & 16,75 & $(2.463,03)$ & $(6,33)$ \\
Permukiman & $6.244,01$ & 16,06 & $9.427,64$ & 24,24 & $3.183,64$ & 8,19 \\
Sawah & $2.817,50$ & 7,25 & $3.682,90$ & 9,47 & 865,41 & 2,23 \\
Tegal/Ladang & $16.422,63$ & 42,23 & $12.581,70$ & 32,35 & $(3.840,94)$ & $(9,88)$ \\
\hline
\end{tabular}

\section{Indeks Konservasi Alami}

Hasil perhitungan indeks konservasi alami KBU didominasi oleh zona konservasi tinggi dengan luas mencapai $27.249,37$ ha atau 70,07\% dari luas wilayah (Tabel 9).

Tabel 9. Indeks Konservasi Alami

\begin{tabular}{cr}
\hline Nilai Indeks Alami & Luas (Ha) \\
\hline Sedang & $1.145,92$ \\
Tinggi & $27.249,37$ \\
Sangat Tinggi & $10.493,05$ \\
Luas (Ha) & $38.888,34$ \\
\hline
\end{tabular}

Zona konservasi sangat tinggi umumnya tersebar di sebelah utara wilayah KBU, sedangkan zona konservasi tinggi tersebar di sebelah selatan. Untuk zona konservasi sedang umumnya menyebar berupa spot-spot kawasan (Gambar 6).

\section{Indeks Konservasi Aktual}

Hasil perhitungan indeks konservasi aktual tahun 2015 didominasi oleh kelas konservasi sedang dengan luas mencapai $16.421,13$ ha atau $42,23 \%$, sedangkan pada tahun 2018 didominasi pula oleh kelas konservasi sedang dengan luas berkurang menjadi $12.581,70$ ha atau $32,35 \%$ (Tabel 10). 


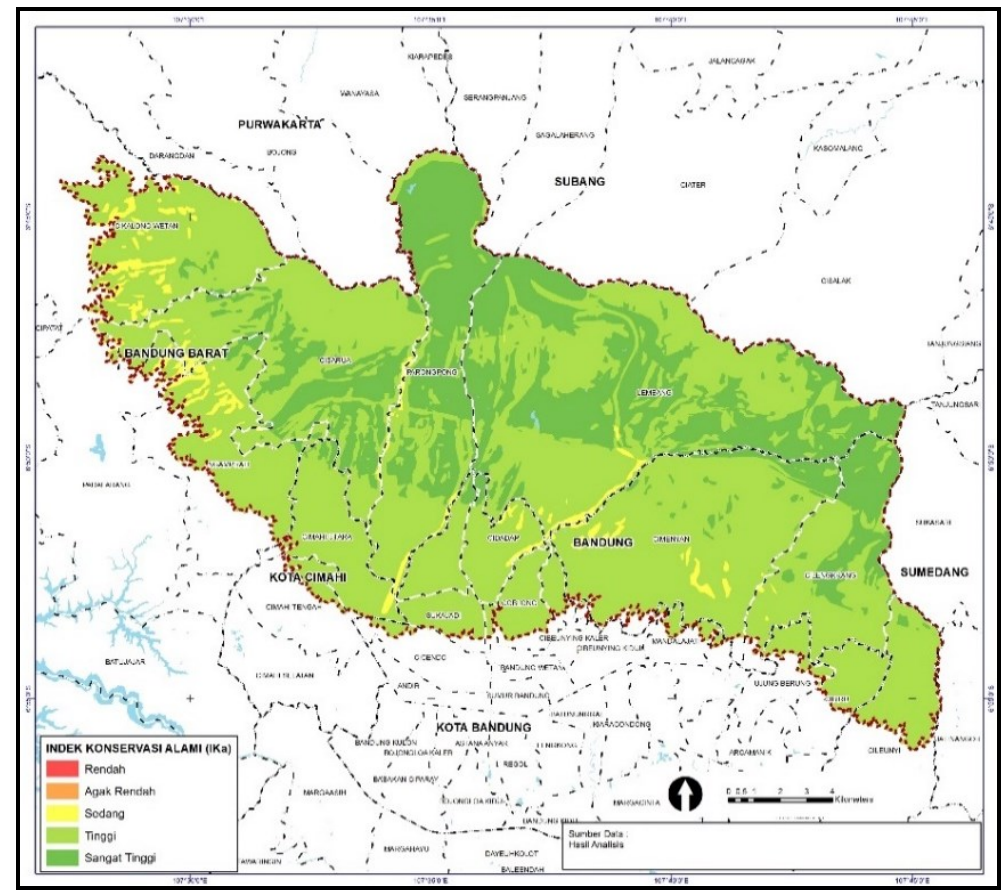

Gambar 6. Indeks Konservasi Alami

Tabel 10. Nilai Perubahan Indeks Konservasi Aktual (IKC) Tahun 2015-2018

\begin{tabular}{lrrrrrr}
\hline \multicolumn{1}{c}{ Kriteria } & \multicolumn{1}{c}{ IKC } & $\mathbf{\%}$ IKC & \multicolumn{1}{c}{ IKC } & $\begin{array}{c}\text { \% IKC } \\
\text { IK15 }\end{array}$ & \multicolumn{1}{c}{$\begin{array}{c}\text { Perubahan } \\
\text { (Ha) }\end{array}$} & \multicolumn{1}{c}{$\begin{array}{c}\text { Perubahan } \\
\text { (\%) }\end{array}$} \\
\hline Rendah & $6.245,51$ & 16,06 & $9.427,64$ & 24,24 & $3.182,14$ & 8,18 \\
Agak Rendah & $2.817,50$ & 7,25 & $3.682,90$ & 9,47 & 865,41 & 2,23 \\
Sedang & $16.421,13$ & 42,23 & $12.581,70$ & 32,35 & $(3.839,43)$ & $(9,87)$ \\
Tinggi & $6.615,39$ & 17,01 & $6.514,52$ & 16,75 & $(100,87)$ & $(0,26)$ \\
Sangat Tinggi & $6.788,81$ & 17,46 & $6.681,57$ & 17,18 & $(107,24)$ & $(0,28)$ \\
\hline
\end{tabular}

Variasi perubahan luas wilayah konservasi aktual yang terjadi pada tahun 2015-2018 diakibatkan perubahan fungsi lahan di bagian selatan KBU. Alih fungsi lahan yang mengubah kawasan konservasi menjadi kawasan budi daya dan lahan terbangun telah menurunkan nilai konservasi aktual. Pemanfaatan lahan yang tidak memerhatikan kaidahkaidah konservasi tanah dan air berpotensi menyebabkan terjadinya degradasi lahan yang pada akhirnya akan menimbulkan lahan kritis (Muttaqin, 2014).

Hasil analisis indeks konservasi menunjukkan tahun 2015 didominasi oleh kelas konservasi kritis dengan luas 26.588,57 ha atau 68,37\%, sedangkan pada tahun 2018 didominasi oleh kelas konservasi kritis pula dengan luas 27.136,90 ha atau 69,78\% (Tabel 11). Kajian Sutrisna et al. (2010) menjelaskan telah mulai ditemukan adanya beberapa lokasi lahan kritis pada tahun 2010. Dari hal tersebut terlihat bahwa temuan dari penelitian ini adalah sebaran lahan kritis di KBU semakin bertambah setiap tahunnya.

Hasil analisis fungsi konservasi pada tahun 2015 dan 2018 menunjukkan bahwa perubahan penggunaan lahan selama periode tersebut telah mengakibatkan pertambahan kelas konservasi kritis sebesar 1,41\% (Gambar 7 dan Gambar 8). Meskipun pada tahun 2015-2018 pertambahan kelas konservasi kritis tidak terlalu signifikan, tetapi hal tersebut telah mengakibatkan penurunan lahan resapan air. Hal ini sesuai dengan kajian Duwila et al. (2019) bahwa penggunaan lahan yang tidak sesuai dengan kemampuannya dan apabila 
tidak diikuti dengan usaha konservasi tanah yang baik akan mempercepat terjadi erosi, sehingga upaya konservasi lahan kritis di KBU perlu segera dilakukan.

Tabel 11. Nilai Indeks Konservasi Tahun 2015 - 2018

\begin{tabular}{lccccrr}
\hline Kriteria & $\begin{array}{c}\text { IKC } \\
\text { 2015 (Ha) }\end{array}$ & $\begin{array}{c}\text { \% IKC } \\
\mathbf{2 0 1 5}\end{array}$ & $\begin{array}{c}\text { IKC } \\
\mathbf{2 0 1 8}(\mathbf{H a})\end{array}$ & $\begin{array}{c}\text { \% IKC } \\
\mathbf{2 0 1 8}\end{array}$ & $\begin{array}{c}\text { Perubahan } \\
\text { (Ha) }\end{array}$ & \multicolumn{2}{c}{$\begin{array}{c}\text { Perubahan } \\
\text { (\%) }\end{array}$} \\
\hline Kritis & $26.588,57$ & 68,37 & $27.136,90$ & 69,78 & 548,33 & 1,41 \\
Normal & $8.273,67$ & 21,28 & $7.558,28$ & 19,44 & $(715,40)$ & $(1,84)$ \\
Baik & $4.026,10$ & 10,35 & $4.193,17$ & 10,78 & 167,07 & 0,43 \\
\hline
\end{tabular}

Perubahan kondisi lahan tidak berubah secara drastis, akan tetapi dilihat dari nilainya yang memiliki kecenderungan penurunan maka perlu dipantau agar penurunan kondisi kesesuaian lahan resapan air tanah tidak semakin besar (Lestiana et al., 2011). Pada lahan yang termasuk kategori kritis, maka perlu dilakukan pemulihan dan pengendalian/pembatasan pembangunan (Rismana \& Firmansyah, 2011).

Permasalahan yang terjadi di KBU adalah peruntukan lahan yang ada tidak sesuai dengan fungsinya sebagai kawasan konservasi daerah resapan air (Wibowo, 2005). Konversi lahan yang terjadi di KBU tidak dapat dihentikan, namun salah satunya dapat diarahkan pada konversi lahan dengan kewajiban penggunaan tanah sesuai peraturan perundang-undangan (Fadjarajani, 2008). Berdasarkan kajian tersebut, maka konversi lahan di KBU dapat diatur dengan dokumen tata ruang yang memerhatikan aspek konservasi.

Undang-Undang Nomor 26 Tahun 2007 tentang Penataan Ruang mengamanatkan rencana tata ruang untuk lintas kabupaten/kota diatur dalam Rencana Tata Ruang Wilayah Provinsi (RTRWP). Salah satu muatan dari RTRWP adalah rencana pola ruang yang mengatur rencana peruntukan ruang untuk 20 tahun yang akan datang (Pemerintah Republik Indonesia, 2007).

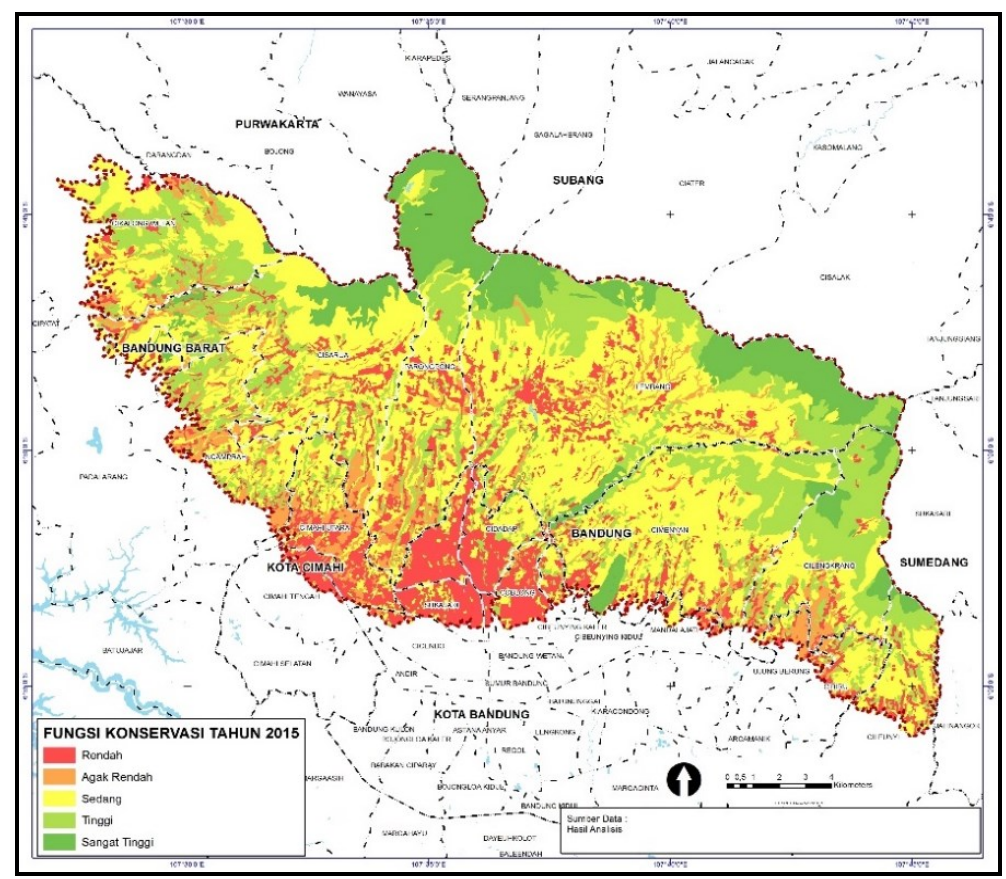

Gambar 7. Fungsi Konservasi Tahun 2015 


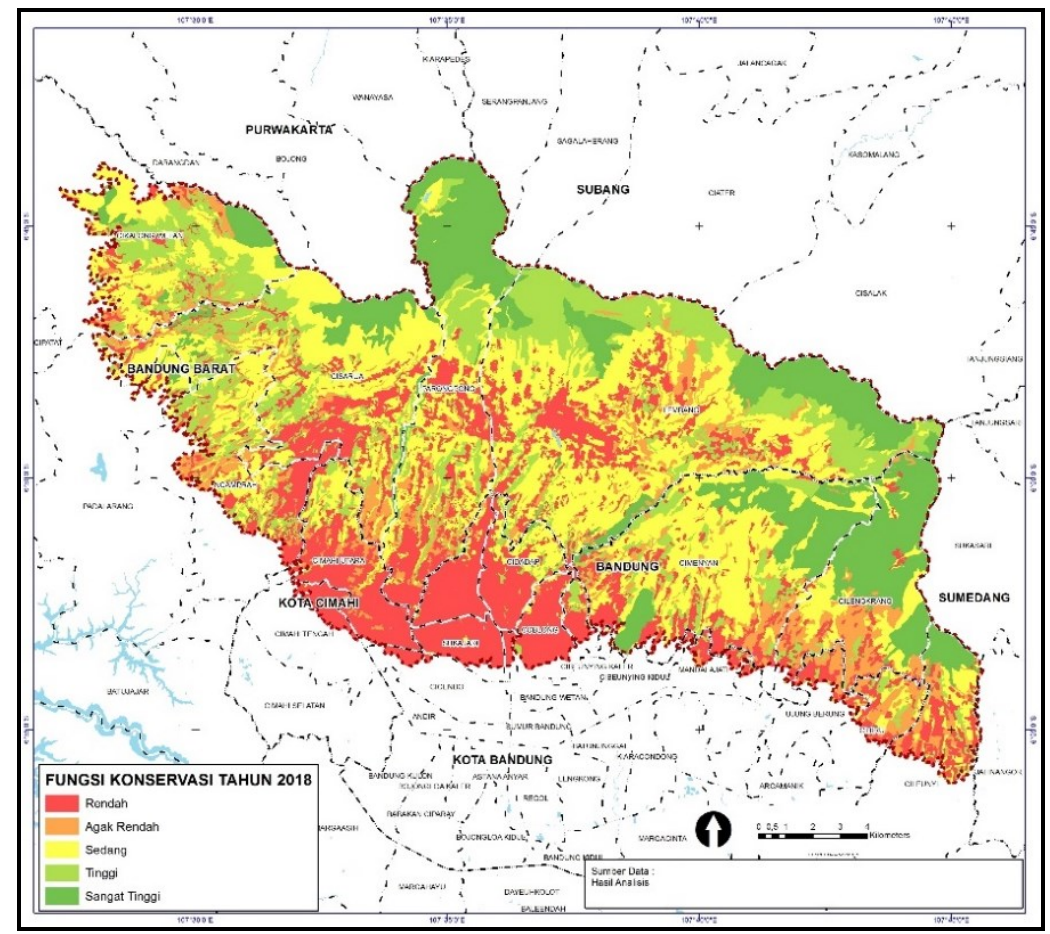

\section{Gambar 8. Fungsi Konservasi Tahun 2018}

Berdasarkan kajian Fadjarajani (2008) dan aturan Undang-Undang Nomor 26 Tahun 2007, dalam penelitian ini ditambahkan parameter fungsi rencana pola ruang RTRWP untuk mengetahui proyeksi indeks konservasi di masa yang akan datang. Berdasarkan hal tersebut, dapat diketahui nilai Indeks Konservasi Rencana (IKR) di KBU berdasarkan dokumen RTRW Provinsi Jawa Barat 2009-2029. Dominasi rencana pola ruang RTRW Provinsi Jawa Barat tahun 2029 adalah kawasan hutan lindung sebesar 23,15\%. Untuk kawasan terbangun di KBU direncanakan sebesar 25,05\% (Gambar 9).

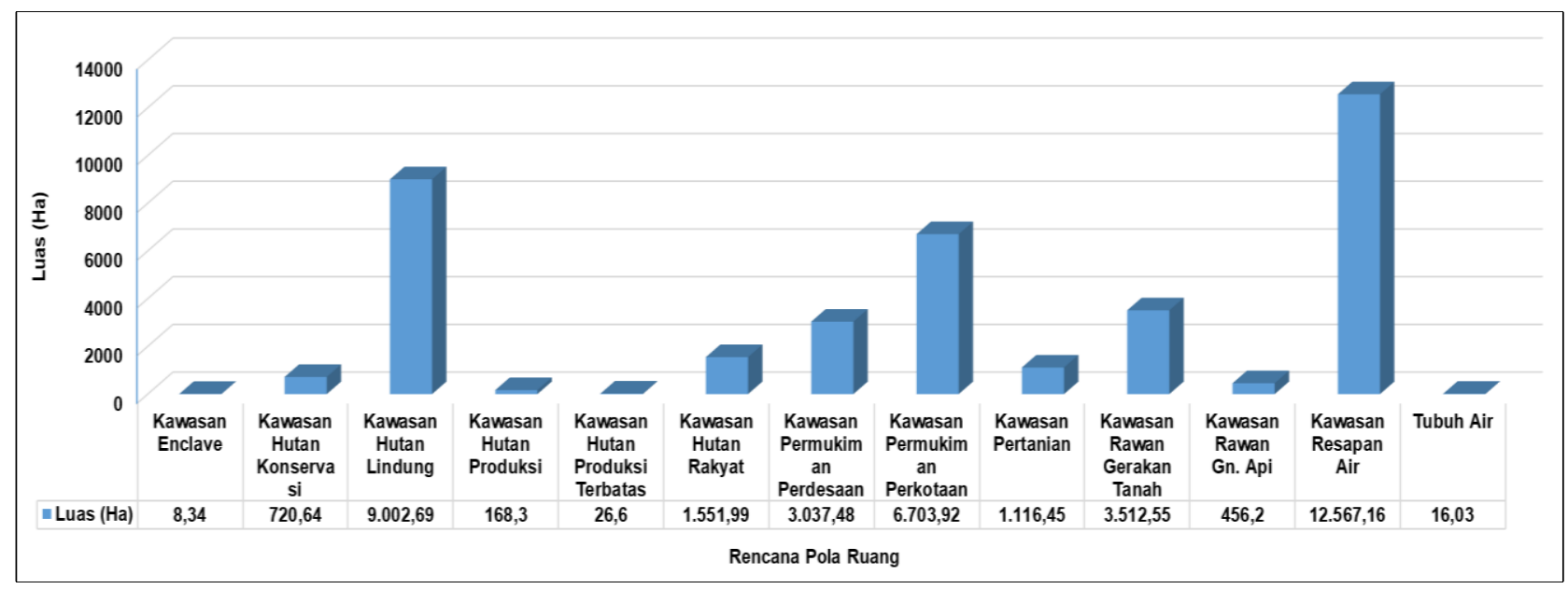

Sumber: Pemerintah Daerah Provinsi Jawa Barat, 2010

Gambar 9. Rencana Pola Ruang KBU Tahun 2029 
Hasil perhitungan indeks konservasi rencana didominasi oleh kelas konservasi sangat tinggi dengan luas mencapai 24.085,09 ha atau 61,93\% (Tabel 12).

Tabel 12. Nilai Perubahan Indeks Konservasi Aktual (IKC) Tahun 2015 terhadap Indeks Konservasi Rencana Tahun 2029

\begin{tabular}{|c|c|c|c|c|c|c|}
\hline Kriteria & $\begin{array}{c}\text { IKC } \\
2018 \text { (Ha) }\end{array}$ & $\begin{array}{c}\text { \% IKC } \\
2018\end{array}$ & $\begin{array}{c}\text { IKR } \\
2029 \text { (Ha) }\end{array}$ & $\begin{array}{c}\text { \% IKR } \\
2029\end{array}$ & $\begin{array}{c}\text { Perubahan } \\
\text { (Ha) }\end{array}$ & $\begin{array}{c}\text { Perubahan } \\
(\%)\end{array}$ \\
\hline Rendah & $9.427,64$ & 24,24 & $10.299,23$ & 26,48 & 871,59 & 2,24 \\
\hline Agak Rendah & $3.682,90$ & 9,47 & $1.376,46$ & 3,54 & $(2.306,44)$ & $(5,93)$ \\
\hline Sedang & $12.581,70$ & 32,35 & $2.279,32$ & 5,86 & $(10.302,38)$ & $(26,49)$ \\
\hline Tinggi & $6.514,52$ & 16,75 & 848,25 & 2,18 & $(5.666,27)$ & $(14,57)$ \\
\hline Sangat Tinggi & $6.681,57$ & 17,18 & $24.085,09$ & 61,93 & $17.403,51$ & 44,75 \\
\hline
\end{tabular}

Tabel 13. Fungsi Konservasi Rencana Tahun 2029

\begin{tabular}{|c|c|c|c|c|c|}
\hline Kabupaten/Kota & Kecamatan & Kritis & Normal & Baik & Luas (Ha) \\
\hline \multirow{3}{*}{ Kab. Bandung } & Cilengkrang & 370,98 & 997,32 & $1.455,34$ & $2.823,64$ \\
\hline & Cileunyi & 727,04 & 110,66 & 243,50 & $1.081,19$ \\
\hline & Cimenyan & $1.756,79$ & 498,49 & $2.763,84$ & $5.019,12$ \\
\hline \multicolumn{2}{|c|}{ Total Kabupaten Bandung } & $2.854,80$ & $1.606,47$ & $4.462,68$ & $8.923,95$ \\
\hline \multirow{6}{*}{ Kab Bandung Barat } & Cikalong Wetan & 179,90 & 74,36 & $2.732,87$ & $2.987,13$ \\
\hline & Cisarua & 904,32 & $1.099,63$ & $3.149,80$ & $5.153,75$ \\
\hline & Lembang & $2.077,30$ & $3.450,99$ & $4.255,35$ & $9.783,65$ \\
\hline & Ngamprah & 960,85 & 114,85 & 959,72 & $2.035,41$ \\
\hline & Padalarang & 1,14 & 0,00 & 240,68 & 241,83 \\
\hline & Parongpong & $2.033,33$ & $1.807,38$ & 523,30 & $4.364,01$ \\
\hline \multicolumn{2}{|c|}{ Total Kabupaten Bandung Barat } & $6.156,85$ & $6.547,22$ & $11.861,72$ & $24.565,79$ \\
\hline \multirow{10}{*}{ Kota Bandung } & Cibeunying Kaler & 11,28 & 0,00 & 0,00 & 11,28 \\
\hline & Cibeunying Kidul & 18,87 & 0,00 & 0,00 & 18,87 \\
\hline & Cibiru & 418,96 & 100,29 & 0,19 & 519,44 \\
\hline & Cicendo & 73,05 & 0,00 & 0,00 & 73,05 \\
\hline & Cidadap & 865,72 & 147,96 & 22,85 & $1.036,54$ \\
\hline & Coblong & 514,67 & 37,79 & 2,24 & 554,71 \\
\hline & Mandalajati & 147,32 & 0,00 & 0,00 & 147,32 \\
\hline & Sukajadi & 463,83 & 0,00 & 0,00 & 463,83 \\
\hline & Sukasari & 619,75 & 6,06 & 0,96 & 626,77 \\
\hline & Ujung Berung & 231,48 & 6,12 & 31,60 & 269,20 \\
\hline \multicolumn{2}{|l|}{ Total Kota Bandung } & $3.364,94$ & 298,22 & 57,84 & $3.721,00$ \\
\hline \multirow{2}{*}{ Kota Cimahi } & Cimahi Tengah & 217,63 & 0,00 & 0,00 & 217,63 \\
\hline & Cimahi Utara & $1.366,16$ & 37,54 & 56,27 & $1.459,97$ \\
\hline \multicolumn{2}{|l|}{ Total Kota Cimahi } & $1.583,79$ & 37,54 & 56,27 & $1.677,60$ \\
\hline \multicolumn{2}{|c|}{ Luas (Ha) } & $13.960,38$ & $8.489,45$ & $16.438,51$ & $38.888,34$ \\
\hline \multicolumn{2}{|c|}{$\%$} & 35,90 & 21,83 & 42,27 & 100,00 \\
\hline
\end{tabular}

Variasi perubahan luas wilayah konservasi aktual tahun 2018 dengan wilayah konservasi pada rencana pola ruang RTRWP Jawa Barat (2029) telah mengubah wilayah konservasi pada kelas sangat tinggi sebesar $44,75 \%$. Hal ini dikarenakan cukup tingginya rencana pengembangan kawasan hutan di KBU, khususnya di wilayah Kabupaten Bandung Barat.

Setelah mengetahui kondisi konservasi alami dan konservasi rencana, kemudian dilakukan tumpang susun terhadap kedua peta tersebut sehingga didapatkan nilai IKR yang merupakan suatu temuan baru dari hasil penelitian ini. Dari analisis indeks konservasi dapat diketahui bahwa fungsi konservasi di KBU tahun 2029 didominasi oleh kelas konservasi baik dengan luas $16.438,51$ ha atau $42,27 \%$ (Tabel 13). Hasil kajian nilai IKR 
dalam penelitian ini dapat membuktikan kajian Fadjarajani (2008) bahwa konversi lahan yang terjadi di KBU tidak dapat dihentikan, namun dapat diarahkan pada konversi lahan dengan kewajiban penggunaan tanah sesuai peraturan perundang-undangan (dalam hal ini dokumen RTRW Provinsi Jawa Barat).

Revisi dan penyempurnaan penataan ruang dengan memanfaatkan instrumen teknologi, peraturan dan perundangan perlu dilakukan untuk mengendalikan dan menekan laju pertumbuhan perumahan di KBU (Masri \& Purwaamijaya, 2011). Hal tersebut tercermin dalam program-program yang terdapat dalam dokumen RTRWP Jawa Barat belum mengarah untuk mengendalikan dan menekan laju perumahan sehingga terwujud kelas konservasi yang baik di KBU pada tahun 2029. Hal ini dapat menyebabkan kebijakan yang telah dibuat menjadi kurang efektif. Untuk mewujudkan kelas konservasi yang baik di KBU pada tahun 2029 diperlukan dukungan program pemanfaatan ruang RTRW dengan prinsip adaptasi dan mitigasi daya dukung lingkungan, yang memerhatikan aspek lingkungan, sosial, dan ekonomi.

\section{Kesimpulan}

Dalam kajian ini diperoleh besaran lahan kritis eksisting (tahun 2018) yang dapat menjadi rekomendasi untuk kebijakan tata ruang terkait kawasan yang tidak diperbolehkan untuk dibangun. Di samping itu dalam kajian ini dihasilkan pula analisis IKR sebagai suatu alat untuk mengetahui efektivitas rencana pola ruang RTRW dengan mempertimbangkan faktor infiltrasi.

Kajian IKA dan IKC dalam penelitian ini memperlihatkan adanya pertambahan sebaran lahan kritis di KBU. Alih fungsi lahan yang terjadi dari tahun 2015 sampai dengan tahun 2018 telah menyebabkan bertambahnya wilayah konservasi kritis sebesar 1,41\%. Sebaran wilayah konservasi kritis ini terutama terjadi di wilayah selatan KBU.

Hasil analisis IKR tahun 2029 dalam penelitian ini menunjukkan rencana pola ruang RTRW Provinsi Jawa Barat akan menurunkan wilayah konservasi kritis di KBU. Hasil analisis IKR membuktikan bahwa rencana pola ruang RTRW Provinsi Jawa Barat akan mampu menurunkan wilayah konservasi kritis pada tahun 2029. Dengan demikian, penelitian ini dapat membuktikan bahwa analisis IKR dapat digunakan sebagai salah satu metode untuk pengendalian pelaksanaan rencana pola ruang RTRW yang telah mempertimbangkan aspek konservasi untuk faktor inflitrasi.

Untuk mendukung kebijakan rencana pola ruang RTRW, maka diperlukan program pemanfaatan ruang yang didasarkan pada analisis IKR untuk mencegah semakin menurunnya fungsi konservasi di KBU. Perwujudan program lingkungan untuk mencapai kelas konservasi baik sebesar 42,27\% pada tahun 2029 diarahkan pada wilayah Kota Bandung (Kecamatan Cibiru, Cidadap, Coblong, Sukasari, dan Ujungberung), Kabupaten Bandung (Kecamatan Cilengkrang, Cileunyi, dan Cimenyan), serta Kabupaten Bandung Barat (Kecamatan Cikalong Wetan, Cisarua, Lembang, Ngamprah, Padalarang, dan Parongpong).

Perwujudan program-program lingkungan untuk mengurangi wilayah konservasi kritis sebesar 35,90\% setelah tahun 2029, terutama pada wilayah kecamatan yang masih memiliki konservasi lahan kritis setelah tahun 2029, meliputi wilayah Kota Bandung (terutama di Kecamatan Cidadap), Kota Cimahi (terutama di Kecamatan Cimahi Utara), Kabupaten Bandung (terutama di Kecamatan Cimenyan), serta Kabupaten Bandung Barat (terutama di Kecamatan Lembang).

Perwujudan program lingkungan lain dalam rangka konservasi KBU meliputi pemulihan kawasan yang mengalami kondisi kritis (melalui reboisasi, penghijauan, pembuatan sumur resapan, dan biopori), memberikan insentif pada kawasan yang berfungsi konservasi pada kategori sangat tinggi dan tinggi, memberikan disinsentif pada 
bangunan-bangunan yang berada di lahan kritis (pengaturan ketat untuk koefisien dasar bangunan), serta perlunya kajian lanjutan terkait program-program dengan prinsip adaptasi dan mitigasi daya dukung lingkungan (untuk mewujudkan tambahan kelas konservasi baik sebesar $42,27 \%)$.

\section{Ucapan Terima Kasih}

Hasil penelitian ini adalah bagian dari tesis sebagai syarat kelulusan S2 pada Program Studi Magister Inovasi Regional, Sekolah Pasca Sarjana Universitas Padjadjaran. Penulis mengucapkan terimakasih kepada ketua program studi, pembimbing dan semua pihak di lingkungan Program Studi Magister Inovasi Regional Sekolah Pascasarjana Universitas Padjadjaran yang telah memberikan bantuan, masukan dan kerjasamanya untuk penerbitan tulisan ini.

\section{Daftar Pustaka}

Adharani, Y., \& Nurzaman, R. A. (2017). Fungsi perizinan dalam pengendalian pemanfaatan ruang di Kawasan Bandung Utara dalam kerangka pembangunan berkelanjutan. Bina Hukum Lingkungan, 2(1), 1-13. doi:10.24970/jbhl.v2n1.1.

Afandi, M. N. (2014). Implementasi kebijakan pembangunan di Kawasan Bandung Utara dalam perspektif pembangunan berwawasam lingkungan. Jurnal Ilmu Administrasi, 11(2), 225-244.

Da Costa, A., Mononimbar, W., \& Takumansang, E. D. (2019). Analisis kesesuaian lahan permukiman Kabupaten Sorong. Jurnal Perencanaan Wilayah dan Kota, 6(3), 692-702.

Duwila, R., Tarore, R. C., \& Takumansang, E. D. (2019). Analisis kemampuan lahan di Pulau Sulawesi Kabupaten Kepulauan Sula. Spasial: Perencanaan Wilayah dan Kota, 6(3), 703-713.

Fadjarajani, S. (2008). Dinamika masyarakat dan konversi lahan pertanian serta pengaruhnya terhadap pengetahuan tentang lingkungan di Kawasan Bandung Utara. Majalah Geografi Indonesia, 22(2), 102123. doi:10.22146/mgi.13319.

Geoportal BIG. (2011). Peta DEM nasional. Retrieved from http://tides.big.go.id/DEMNAS/.

Geoportal BIG. (2015). Peta rupa bumi Indonesia. Retrieved from https://tanahair.indonesia.go.id/portal-web/.

Geoportal BMKG. (2015). Curah hujan tahunan (rata-rata dari 2006-2015). Retrieved from http://gis.bmkg.go.id/arcgis/rest/services/KSP/peta_KSP/MapServer/3.

Geoportal Lapan. (2018). Citra satelit resolusi tinggi (CSRT) Spot 5. Retrieved from https://inderajacatalog.lapan.go.id/DD4/.

Hernawan, E., Kartodiharjo, H., Darusman, D., \& Soedomo, S. (2009). Insentif ekonomi dalam penggunaan lahan (land use) Kawasan Lindung di Kawasan Bandung Utara (incentive of economy for land use in the North Bandung Area). Jurnal Manajemen Hutan Tropika, 15(2), 45-53. doi:10.7226/jmht.15.2.

Lestiana, H., Maria, R., Mulyono, A., Mulyadi, D., Sukristiyanti, S., \& Fakhrurrozi, A. (2011). Kajian kondisi lahan berdasarkan indeks konservasi di wilayah pengembangan Jalancagak Kabupaten Subang. Prosiding Pemaparan Hasil Penelitian Puslit Geoteknologi - LIPI, 111-120.

Lestiana, H., Mulyono, A., Maria, R., \& Mulyadi, D. (2019). Kesesuaian lahan berdasarkan indeks konservasi secara spasial di DAS Ciasem Hulu, Subang. LIMNOTEK Perairan Darat Tropis di Indonesia, 26(2), 119129. doi:10.14203/limnotek.v26i2.213.

Litbang Pertanian. (2017). Lembar: Jawa Barat skala 1: 50.000 tahun 2017. Retrieved from http://sisultan.litbang.pertanian.go.id.

Maria, R., \& Lestiana, H. (2014). Pengaruh penggunaan lahan terhadap fungsi konservasi air tanah di Sub Das Cikapundung. Jurnal RISET Geologi dan Pertambangan, 24(2), 77-89. doi:10.14203/risetgeotam2014.v24.85.

Marselina, M., Jatikusuma, I., \& Sabar, A. (2020). The conservation index as a control instrument of space utilisation in the Upper Cikapundung Watershed of Indonesia. International Journal of Hydrology Science 


\section{Kajian Daya Dukung Lingkungan dalam Pemanfaatan Ruang di Kawasan Bandung Utara}

and Technology, 192), 148-166. doi:10.1504/IJHST.2020.106508.

Masri, R. M., \& Purwaamijaya, I. M. (2011). Analisis dampak lingkungan untuk pembangunan perumahan di Kawasan Bandung Utara berbasis model sistem dinamis. Jurnal Permukiman, 6(3), 147-153. doi:10.31815/jp.2011.6.147-153.

Muttaqin, T. (2014). Evaluasi kekritisan lahan di Kawasan Lindung Kecamatan Pujon Kabupaten Malang Jawa Timur dengan teknologi sistem informasi geografis. Jurnal Gamma, 19(1), 135-142.

Nurrachman, M. H. Z., Sumardi, I., \& Lastini, T. (2018). Land cover and groundwater recharge changes study using conservation index in the Highland Ciburial Village, Bandung Regency. IOP Conference Series: Earth and Environmental Science, 166, 1-6. doi:10.1088/1755-1315/166/1/012036.

Nurrochman, E., Joy, B., \& Asdak, C. (2018). Kajian sistem hidrologi akibat perubahan tataguna lahan di Kawasan Bandung Utara (studi kasus Kabupaten Bandung Barat). Envirosan, 1(1), 25-30.

Pemerintah Daerah Provinsi Jawa Barat. (2010). Peraturan Daerah Provinsi Jawa Barat No. 22 Tahun 2010 tentang rencana tata ruang wilayah Provinsi Jawa Barat 2009-2029.

Pemerintah Daerah Provinsi Jawa Barat. (2016). Peraturan Daerah Provinsi Jawa Barat No. 2 Tahun 2016 tentang pedoman pengendalian Kawasan Bandung Utara sebagai Kawasan Strategis Provinsi Jawa Barat.

Pemerintah Republik Indonesia. (2007). Undang-Undang No. 26 Tahun 2007 tentang penataan ruang.

Pemerintah Republik Indonesia. (2018). Peraturan Presiden No. 45 Tahun 2018 tentang rencana tata ruang Kawasan Perkotaan Cekungan Bandung.

Putri, N. P., \& Purwadio, H. (2013). Arahan pengendalian alih fungsi daerah resapan air menjadi lahan terbangun di Kecamatan Lembang, Bandung. Jurnal Teknik Pomits, 2(1), 1-6.

Rismana, G. A., \& Firmansyah, F. (2011). Evaluasi pemanfaatan ruang berdasarkan indeks konservasi di Sub DAS Cikapundung Hulu Provinsi Jawa Barat. Jurnal Lingkungan dan Bencana Geologi, 2(1), 49-66. doi:10.34126/jlbg.v2i1.16.

Sagita, N. I. (2016). Strategi gerakan kelompok kepentingan dalam pengawasan pengendalian pemanfaatan ruang Kawasan Bandung Utara. Jurnal Wacana Politik, 1(2), 96-106. doi:10.24198/jwp.v1i2.11051.

Silitonga, P. (1973). Peta Geologi Lembar Bandung, Jawa, Skala 1:100.000.

Sugiyono. (2017). Metoda penelitian kuantitatif, kualitatif, dan $r \& d$. Bandung: PT. Alfabeta.

Sutrisna, N., Sitorus, S. R., \& Subagyono, K. (2010). Tingkat kerusakan tanah di Hulu Sub DAS Cikapundung Kawasan Bandung Utara. Jurnal Tanah dan Iklim, 32, 71-82.

Tigana, P., \& Sabar, A. (2019). Drainase wawasan lingkungan di Kawasan Konservasi Air Bopuncur. Jurnal Teknik Lingkungan, 25(1), 57-72.

Wibowo, M. (2005). Kajian atas hasil-hasil penelitian kawasan konservasi daerah resapan air di Cekungan Bandung. Jurnal Teknologi Lingkungan, 6(3), 463-468. 